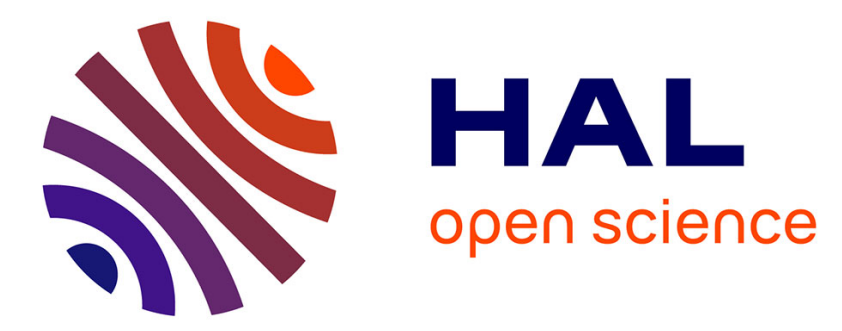

\title{
A 70 Ma record of suprasolidus conditions in the large, hot, long-duration Grenville Orogen
}

François Turlin, Clara Deruy, Aurélien Eglinger, Olivier Vanderhaeghe, Anne-Sylvie André-Mayer, Marc Poujol, Abdelali Moukhsil, Fabien Solgadi

\section{- To cite this version:}

François Turlin, Clara Deruy, Aurélien Eglinger, Olivier Vanderhaeghe, Anne-Sylvie André-Mayer, et al.. A 70 Ma record of suprasolidus conditions in the large, hot, long-duration Grenville Orogen. Terra Nova, 2018, 30 (3), pp.233-243. 10.1111/ter.12330 . hal-01778709

\section{HAL Id: hal-01778709 \\ https://hal.science/hal-01778709}

Submitted on 25 Apr 2018

HAL is a multi-disciplinary open access archive for the deposit and dissemination of scientific research documents, whether they are published or not. The documents may come from teaching and research institutions in France or abroad, or from public or private research centers.
L'archive ouverte pluridisciplinaire HAL, est destinée au dépôt et à la diffusion de documents scientifiques de niveau recherche, publiés ou non, émanant des établissements d'enseignement et de recherche français ou étrangers, des laboratoires publics ou privés. 
MR. FRANÇOIS TURLIN (Orcid ID : 0000-0002-0378-6972)

Article type : Paper

Received date: $10-O c t-2017$

Revised version received date: $27-J a n-2018$

Accepted date: $29-J a n-2018$

\section{A 70 Ma record of suprasolidus conditions in the large, hot, long-duration Grenville Orogen}

François Turlin",*, Clara Deruy ${ }^{1}$, Aurélien Eglinger ${ }^{1}$, Olivier Vanderhaeghe ${ }^{2}$, AnneSylvie André-Mayer ${ }^{1}$, Marc Poujol ${ }^{3}$, Abdelali Moukhsil ${ }^{4}$, Fabien Solgadi ${ }^{4}$

${ }^{1}$ GeoRessources lab., UMR 7359, Université de Lorraine, CNRS, CREGU, Faculté des Sciences et Technologies, Vandouvre-lès-Nancy, F-54506, France

${ }^{2}$ Géosciences Environnement Toulouse, GET, Université de Toulouse, CNRS, IRD, UPS, CNES (Toulouse), France

${ }^{3}$ Univ Rennes, CNRS, Géosciences Rennes - UMR 6118, F-35000 Rennes, France

4 Ministère de l'Énergie et des Ressources naturelles, Direction du Bureau de la connaissance géoscientifique du Québec (Canada)

* Corresponding author at: François Turlin

Université de Lorraine, CNRS, CREGU, GeoRessources lab.

Campus Aiguillettes, Faculté des Sciences et Technologies

rue Jacques Callot

This article has been accepted for publication and undergone full peer review but has not been through the copyediting, typesetting, pagination and proofreading process, which may lead to differences between this version and the Version of Record. Please cite this article as doi: $10.1111 /$ ter. 12330

This article is protected by copyright. All rights reserved. 
Vandœuvre-lès-Nancy, F-54506, France.

Mail: francois.turlin@univ-lorraine.fr

Phone: +33 383684767

\section{ABSTRACT}

Petrochronology of magmatic monazite and apatite from a single paragneiss leucosome derived by in-situ partial melting documents the thermal evolution of the Allochthonous Belt of the central Grenville Province. Monazite records suprasolidus metamorphism from ca. 1080 to $1020 \mathrm{Ma}$ under high temperature up to $850^{\circ} \mathrm{C}$. Apatite from the same leucosome yields an age of $960 \mathrm{Ma}$, consistent with cooling of this crustal segment down to subsolidus conditions of ca. $450^{\circ} \mathrm{C}$. A pegmatitic granite dyke, with lobate contacts, previously dated at ca. $1005 \mathrm{Ma}$ (Turlin et al., 2017) is interpreted to intrude the paragneisses at a temperature of ca. $650^{\circ} \mathrm{C}$ close to the wet-solidus. These data document slow cooling at a rate of 2 to $6^{\circ} \mathrm{C} / \mathrm{Ma}$ for the middle crust of this part of the Grenville hinterland marked by protracted suprasolidus conditions for at least $70 \mathrm{Ma}$. It supports the definition of the Grenville Orogen as a large, hot, long-duration orogen.

\section{INTRODUCTION}

The term petrochronology was recently defined to designate geochronological studies that integrate the textural and microstructural position of the dated minerals (Engi et al., 2017). Several authors have shown that the use of petrochronological data coupled with thermo-mechanical models can provide new clues to decipher the crustal evolution of orogenic belts (e.g. Brown, 2014; Vanderhaeghe, 2012). The timing and duration of metamorphic processes in a variety of tectonothermal environments are still debated, 
especially for continental collisions marked by high temperature metamorphism (e.g. Johnson et al., 2015; Kohn, 2008). A crucial question is how long the rocks comprising the mid to lower crust remained at suprasolidus temperatures in large, hot, long-duration orogens such as the Himalaya-Tibet Orogen, where the evolution of the Tibetan Plateau is controlled by lateral flow (Jamieson et al., 2004; Nelson et al., 1996; Vanderhaeghe, 2009).

The exhumed root of the Proterozoic Grenville Orogen, composed of intensely deformed, high-grade metamorphic rocks exposed in southern Canada and the northeastern USA (Fig. 1a), presents an ideal opportunity to investigate the deep crustal processes occurring during a long-lived continental collision. Indeed, the Grenville Province was one of the classic localities for the first studies on mineral cooling ages (e.g. Harper, 1967). These rocks underwent protracted granulite-facies conditions under an orogenic plateau similar to the present Tibetan plateau (e.g. Indares and Dunning, 2004; Rivers, 2008; Rivers et al., 2012). In the central Grenville Province in Quebec, suprasolidus growth of monazite has been documented in aluminous gneisses from the mid- to low-pressure segment of the Allochthonous Belt (aM-LP, Fig. 1b) between ca. 1070 and 1020 Ma during a clockwise $P-$ $T-t$ path (Lasalle and Indares, 2014; Lasalle et al., 2014). However, the actual duration of suprasolidus conditions in this aM-LP segment remains unconstrained. In this study, we use $\mathrm{U}-\mathrm{Th}-\mathrm{Pb}$ dating of monazite and apatite from a single leucosome in migmatitic paragneisses from the same area of the central Grenville Province (Complexe de la Plus-Value, Fig. 1c) to better constrain the duration of suprasolidus metamorphic conditions.

This article is protected by copyright. All rights reserved. 


\section{MONAZITE-APATITE CRYSTALLIZATION AND COOLING IN ANATECTIC ALUMINOUS GNEISSES}

\section{1. $\quad \boldsymbol{P}-\boldsymbol{T}-t$ record of the central Grenville Province}

The Grenvillian Orogeny has been described as a two-phase late-Mesoproterozoic to early-Neoproterozoic continental collision involving the Laurentian and Amazonian cratons (Jamieson et al., 2007; Rivers, 2008; Rivers et al., 2012). The older Ottawan phase, for which ages spread from ca. 1090 to $1020 \mathrm{Ma}$, is interpreted as a long-lived period of a large hot orogeny. During the Ottawan period, the Allochthon Boundary Thrust (ABT) is inferred to have played the role of a shallow-dipping crustal scale ramp accommodating lateral extrusion of the ductile mid-crust parallel to the orogenic belt (Rivers, 2008; Rivers et al., 2012). In the aM-LP segment south of the Manicouagan Reservoir, the Ottawan high-grade peak of metamorphism is recorded as a moderate-gradient $P-T$ path, up to sillimanite-grade with $P-T$ conditions of ca. $950 \mathrm{MPa}$ and $850^{\circ} \mathrm{C}$ interpreted to represent the thermal peak (Lasalle and Indares, 2014; Rivers et al., 2012). Two studies have investigated the timing of the Ottawan phase in this area by $\mathrm{U}-\mathrm{Pb}$ dating of monazite from anatectic gneisses (metapelites and aluminous gneisses, Fig. 1c, Dunning and Indares, 2010; Lasalle et al., 2014). These studies have yielded ages ranging from ca. 1080 to $1020 \mathrm{Ma}$, with a dominant cluster at ca. 1070$1050 \mathrm{Ma}$ (maximum temperature), and with ages spreading down to ca. $1025 \mathrm{Ma}$ (LA-ICPMS, Lasalle et al., 2014) and 1020 \pm 2 Ma (ID-TIMS, Dunning and Indares, 2010). These ages are recorded by (i) prograde monazite grains shielded in peritectic garnet $\left({ }^{207} \mathrm{~Pb} /{ }^{206} \mathrm{~Pb}\right.$ ages as old as $1098 \pm 38 \mathrm{Ma}$, Lasalle et al., 2014), and by (ii) monazite grains from the matrix. The complex dissolution/precipitation textures of monazite from the matrix and the large range of ages was interpreted as the consequence of distinct monazite growth events in response to several melt crystallization pulses by these authors. In contrast, in the western Grenville

This article is protected by copyright. All rights reserved. 
Province, a similar spread of zircon $\mathrm{U}-\mathrm{Pb}$ ages between ca. 1090 and $1040 \mathrm{Ma}$ was interpreted as reflecting a 20 to $30 \mathrm{Ma}$ long partial melting event at mid-crust level (Slagstad et al., 2004).

In the aluminous gneisses from the central Grenville Province, an even younger group of ages of ca. 1010-990 Ma is restricted to rims of monazite from the matrix and has been attributed to fluid circulations under greenschist-facies $P-T$ conditions on the basis of chlorite filling garnet cracks and pseudomorphs of sillimanite by aggregates of what is considered to be sericite (Lasalle et al., 2014). However, the textural setting of the dated monazite was not reported, and geochronological evidence supporting the coeval formation of chlorite and monazite rims is lacking. Slightly younger ages published from this area include $\mathrm{U}-\mathrm{Pb}$ titanite results between ca. 995 to $987 \mathrm{Ma}$, determined from pre-Grenvillian and Grenvillian metatuffs and metagranite with protolith ages of ca. 1410 Ma (Dunning and Indares, 2010), ca. $1200 \mathrm{Ma}$ (Indares and Dunning, 2004) and ca. $1065 \mathrm{Ma}$ (Dunning and Indares, 2010). The titanite ages were interpreted to record a late-Grenvillian magmatic/metamorphic/deformation event that occurred under ductile-brittle conditions, consistent with the subsolidus closure temperature of titanite at ca. $550-650^{\circ} \mathrm{C}$ (Schoene and Bowring, 2007 and references therein; Yakymchuk et al., 2017). These younger ages are coeval with the Rigolet tectonic phase attributed to crustal thickening at ca. 1005-960 Ma (Jannin et al., accepted; Rivers, 2008; Rivers et al., 2012; van Gool et al., 2008) recorded in the underlying Parautochthonous Belt with a high-grade peak of metamorphism up to $1250-1500 \mathrm{MPa}$ and $815-850^{\circ} \mathrm{C}$ (Jordan et al., 2006). The 10 to 20 Ma hiatus in ages in the Grenville Province has been interpreted to correspond to the transition from post-Ottawan orogenic gravitational collapse to renewed crustal thickening during the Rigolet tectonic phase (Rivers, 2008).

This article is protected by copyright. All rights reserved. 


\subsection{Petrochronology of monazite and apatite from migmatitic paragneisses}

Migmatitic paragneisses from the Complexe de la Plus-Value of the central Grenville Province sampled for this study (Fig. 1c) have deposition ages comprised between ca. 1.6 and 1.5 $\mathrm{Ga}(\mathrm{U}-\mathrm{Pb}$ on detrital zircon cores and on zircon from the intrusive Bardoux Plutonic Suite, Augland et al., 2015; Lasalle et al., 2013; Moukhsil et al., 2014). They are composed of cm-size leucosomes and melanosomes underlining the syn-migmatitic foliation (Fig. 2a,b). They are intruded by a $1005 \pm 4.4 \mathrm{Ma}(\mathrm{U}-\mathrm{Pb}$ dating on magmatic monazite, Turlin et al., 2017) pegmatitic granite dyke (PGD) (Fig. 2a). The walls of the dyke do not correspond to fractures cutting across minerals of the migmatitic paragneiss but are rather lobate suggesting intrusion in a ductile rock. Moreover, the paragneisses do not show evidence for contact metamorphism (Fig. 2a). These features indicate a close to wet-solidus temperature of the latter at that time (Vanderhaeghe, 2001), i.e. above ca. $650-700^{\circ} \mathrm{C}$ in such metapelites (e.g. Yakymchuk and Brown, 2014). Investigated monazite and apatite grains were sampled from a single leucosome of this migmatitic paragneisses.

Leucosomes show a magmatic texture (Fig. 2b,c) and are composed of a coarse grained (1-5 mm) assemblage of subhedral to euhedral and undeformed quartz and plagioclase with peritectic K-feldspar and garnet (45:35:15:5, Figs. 2c,d). In addition, some biotite show a corroded, nearly skeletal, texture and are separated from garnet by K-feldspar (Fig. 2d). As identified by Lasalle et al. (2014), subhedral, uncorroded and inheritance-free monazite grains $(100-300 \mu \mathrm{m})$ are found (i) as inclusions in peritectic garnet (Fig. 2e) and Kfeldspar, and (ii) in the matrix. These monazite grains have homogeneous compositions with significant components of cheralite and xenotime end-members (Table S1), consistent with the observations of Lasalle et al. (2014). Plotted on a Concordia diagram, U-Th-Pb isotopic data spread along the Concordia curve with ${ }^{208} \mathrm{~Pb} /{ }^{232} \mathrm{Th}$ ages ranging between $1077 \pm 26$ and 
1049 $\pm 25 \mathrm{Ma}$ (2, Fig. 3a, Table 1). No inherited ages were identified in the isotopic ratios, consistent with the homogeneous and unzoned character of the grains.

Apatite grains $(300-600 \mu \mathrm{m})$ occur as stubby and euhedral to subhedral grains in the leucosome matrix (Fig. 2c,f). Along with their shape, the lack of inherited cores/domains or dissolution/precipitation textures, and their homogeneous compositions (Table S2), provide evidence for the crystallization of apatite grains in equilibrium with the residual melt (Fig. $2 \mathrm{c}, \mathrm{f})$. Since apatite generally exhibit a low radiogenic- $\mathrm{Pb} / \mathrm{common}-\mathrm{Pb}$ ratio, the data were plotted in a Tera-Wasserburg diagram (Tera and Wasserburg, 1972), in which the variable ${ }^{206} \mathrm{~Pb} /{ }^{207} \mathrm{~Pb}$ ratios define a discordia line with a lower intercept of $960 \pm 10 \mathrm{Ma}$ (MSWD=1.11,

Fig. 3b, Table 2) and an initial ${ }^{206} \mathrm{~Pb} /{ }^{207} \mathrm{~Pb}$ ratio of 0.90 consistent with the model evolution of Stacey and Kramers (1975). The closure temperatures of these crystals were calculated between $526 \pm 24$ and $459 \pm 22^{\circ} \mathrm{C}$, using the equation of Dodson (1973) and data from Cherniak et al. (1991) (Table 3).

\section{DISCUSSION AND SUMMARY}

\subsection{Protracted suprasolidus conditions}

Monazite grains investigated in this study share (i) microstructural settings and (ii) a range of $\mathrm{U}-\mathrm{Th}-\mathrm{Pb}$ ages similar to the ca. $1080-1020$ Ma monazite grains from aluminous gneisses of this aM-LP segment reported by Dunning and Indares (2010) and Lasalle et al. (2014). Accordingly, we infer that the studied migmatitic paragneiss records similar $P-T-t$ conditions at ca. $950 \mathrm{MPa}$ and $850^{\circ} \mathrm{C}$ between ca. 1070-1050 Ma (Fig. 4) and represents a suitable sample to investigate the retrograde $P-T-t$ path.

Reaction sequences for the clockwise $P-T$ path published by Lasalle and Indares (2014) involve three main partial melting reactions for these paragneisses: (i) the consumption of free aqueous fluid, (ii) the muscovite dehydration-melting reaction, and (iii) 
the biotite dehydration-melting reaction. Monazite grains shielded within peritectic Kfeldspar and garnet (Fig. 2e) formed, respectively, by the incongruent melting of muscovite at ca. $700-750^{\circ} \mathrm{C}$ and the partial incongruent melting of biotite at ca. $800-850^{\circ} \mathrm{C}$. Evidence for the latter are given by some biotite grains that are separated from garnet by K-feldspar and that show a corroded texture, nearly skeletal (Fig. 2d). This feature is expected during biotite dehydration melting, a melt-producing reaction (Kriegsman and Alvarez-Valero, 2010). As proposed by Lasalle et al. (2014), these grains grew during prograde heating and partial melting between ca. 700 and $850^{\circ} \mathrm{C}$ (Kelsey et al., 2008; Yakymchuk and Brown, 2014) and thus correspond to prograde suprasolidus monazite (Yakymchuk, 2017).

Accordingly, data obtained on monazite from this study along with data reported by Dunning and Indares (2010) and Lasalle et al. (2014) point to the crystallization of monazite (i) during the prograde $P-T$ path as early as ca. $1080 \mathrm{Ma}$ under temperatures of at least 700 $750^{\circ} \mathrm{C}$, with (ii) a maximum temperature of $850^{\circ} \mathrm{C}$ between ca. 1070 and $1050 \mathrm{Ma}$, and (iii) down to ca. $1020 \mathrm{Ma}$, during the retrograde $P-T$ path (Fig. 4). The assumption that younger monazite ages between ca. 1010-990 Ma (Lasalle et al., 2014) are coeval with greenschistfacies conditions is reappraised on the basis of the textural relationships between the investigated paragneisses and the intrusive PGD at ca. $1005 \mathrm{Ma}$ (Fig. 2a, Turlin et al., 2017). The lobate contact of the PGD with its host paragneisses in this aM-LP segment imply limited or negligible thermal exchange and thus a close to wet-solidus (ca. $650-700^{\circ} \mathrm{C}$ ) temperature of the host rock at the time of intrusion (Figs. 2a, 4, Turlin et al., 2017).

These features are consistent with a long-duration, mid-crustal residence of this aMLP segment under suprasolidus conditions between ca. 1080 and $1005 \mathrm{Ma}$ in the central Grenville Province, i.e. suprasolidus conditions lasted for at least $70 \mathrm{Ma}$ (Figs. 4, 5a,b). A key point to explain such a long residence at $H T$ may be found in the proposition of a synOttawan extrusion of ductile mid- to low-crust over the ABT associated with some form of 
channel flow (Rivers, 2008) that was, however, inferred to have terminated by ca. 1050 Ma. In contrast, data presented here are suggestive of persistence of a melt fraction in the Ottawan channel for at least ca. 70 Ma (Fig. 5a,b). This thermal-tectonic evolution, comparable to the one inferred for the Cenozoic Himalaya-Tibet orogenic belt (Nelson et al., 1996; Royden et al., 1997, 2008; Searle et al., 2011; Vanderhaeghe and Teyssier, 2001), is tentatively interpreted to reflect the impact of a long-lived thickened orogenic crust associated with delamination or retreat of the lithospheric mantle.

\subsection{Subsolidus thermal history}

The youngest Grenvillian metamorphic ages reported in this aM-LP segment range from $987 \pm 11$ to $995 \pm 3 \mathrm{Ma}$ and were obtained on titanite from (i) pre-Grenvillian metatuffs and metagranite (protolith ages of ca. 1410 Ma, Dunning and Indares, 2010, and ca. 1200 Ma, Indares and Dunning, 2004), and from (ii) a syn-Ottawan metagranite (protolith age of ca. $1065 \mathrm{Ma}$, Dunning and Indares, 2010). They are interpreted as a signal of a late-Grenvillian magmatic/metamorphic/deformation event under semi-brittle conditions, consistent with the subsolidus closure temperature of titanite at ca. $550-650^{\circ} \mathrm{C}$ (Fig. 4, Dunning and Indares, 2010; Indares and Dunning, 2004; Schoene and Bowring, 2007 and references therein; Yakymchuk et al., 2017). Apatite grains from the leucosome crystallized in equilibrium with the residual melt as indicated by their textural setting, their homogeneous compositions, and their lack of inherited cores/domains or dissolution/precipitation textures (Fig. 2c,f, Table 2, S2). Their crystallization ages at $960 \pm 10 \mathrm{Ma}$ (Fig. 3b) along with their estimated closure temperature between $526 \pm 24$ and $459 \pm 22^{\circ} \mathrm{C}$ (Table 3) support the conclusion that this aM-LP crustal segment remained above $450-500^{\circ} \mathrm{C}$ for at least ca. $110 \mathrm{Ma}$ (Figs. 4, 5c).

We propose to integrate the thermal evolution of the central Grenville Province described in this study at the lithospheric scale. This geodynamic model, following Rivers 
(2012) and Corriveau and Morin (2010), invokes asthenospheric upwelling beneath the Grenville belt as recorded by coeval mantle and crustal derived magmatism from ca. 1050 to ca. $960 \mathrm{Ma}$ (Fig. 5). We favour a model of lithospheric thinning by slab retreat but it should be mentioned that delamination by convective removal would also account for these features. Similar scenarios have been proposed for the magmatic record of the Variscan belt (Laurent et al., 2017; Moyen et al., 2017) and for the Indosinian Songpan Ganze terrane (de Sigoyer et al., 2014).

Data from this study coupled with results of Dunning and Indares (2010), Indares and Dunning (2004), Lasalle et al. (2014) and Lasalle and Indares (2014) in the Allochthonous Belt of the central Grenville Province allowed the estimations of cooling rates from the earlyOttawan initiation of suprasolidus conditions to the post-Ottawan cooling down to subsolidus conditions (Table 4). The estimated cooling rates are (i) 2.3 to $4.4^{\circ} \mathrm{C} / \mathrm{Ma}$ for the Ottawan period and (ii) 1.8 to $7.5^{\circ} \mathrm{C} / \mathrm{Ma}$ for the post Ottawan period (Table 4), with most data consistent with a narrower range of 2.7 to $6.1^{\circ} \mathrm{C} / \mathrm{Ma}$. Post-Ottawan rates are similar to those reported for aM-LP rocks of the southwestern Grenville Province determined from ${ }^{40} \mathrm{Ar} /{ }^{39} \mathrm{Ar}$ of hornblende, muscovite, biotite and K-feldspar (see Rivers et al., 2012 and references therein) and more generally for ca. 1 Ga old orogens (Dunlap, 2000). These data indicate that the central Grenville Province exposes the exhumed mid- to lower-part of a large, hot and long-duration orogen that recorded protracted $H T$ metamorphism in the presence of melt for at least ca. $70 \mathrm{Ma}$ followed by a slow cooling history (Figs. 4, 5).

\section{ACKNOWLEDGMENTS}

This work was funded by the Labex Ressources 21 (supported by the French National Research Agency) through the national program "Investissements d'avenir", reference ANR10-LABX-21-LABEX RESSOURCES 21 and the Région Grand-Est, and benefited from the 
framework of the DIVEX "Rare earth element" research program. Authors are grateful to the Ministère de l'Énergie et des Ressources naturelles (Québec) for technical and financial support for field work and analyses, to Alexandre Crépon, Frédéric Diot (GeoRessources, Nancy), Emmanuel Davy (CRPG, Nancy), Andreï Lecomte and Jean Cauzid (GeoRessources, Nancy) for their help in field work, sample preparation and SEM imaging, respectively, to Anthony Pochon (Géosciences Rennes) for his help in handling closure temperatures of apatite, to Flavien Choulet for his constructive comments on a previous version of the manuscript, and to Félix Gervais for our discussions on the geodynamic context of the Grenvillian Orogeny. The authors also thank Toby Rivers, an anonymous reviewer and the associate editor for their careful review that significantly improved the manuscript, and Klaus Mezger for his constructive comments and editorial handling. This contribution is the Ministère de l'Énergie et des Ressources naturelles du Québec (Canada) publication $\mathrm{n}^{\circ}$ 8449-2017-2018-03.

\section{REFERENCES}

Augland, L.E., Moukhsil, A., Solgadi, F., Indares, A. and McFarlane, C., 2015. Pinwarian to Grenvillian magmatic evolution in the central Grenville Province: new constraints from ID-TIMS U-Pb ages and coupled Lu-Hf S-MC-ICP-MS data: Canadian Journal of Earth Sciences, 52, p. 701-721, doi: 10.1139/cjes-2014-0232.

Ballouard, C., Boulvais, P., Poujol, M., Gapais, D., Yamato, P., Tartèse, R. and Cuney, M., 2015. Tectonic record, magmatic history and hydrothermal alteration in the Hercynian Guérande leucogranite, Armorican Massif, France: Lithos, 220-223, p. 1-22, doi: 10.1016/j.lithos.2015.01.027.

This article is protected by copyright. All rights reserved. 
Brown, M., 2014. The contribution of metamorphic petrology to understanding lithosphere evolution and geodynamics: Geoscience Frontiers, 5, p. 553-569, doi: 10.1016/j.gsf.2014.02.005.

Cherniak, D.J., Lanford, W.A. and Ryerson, F.J., 1991. Lead diffusion in apatite and zircon using ion implantation and Rutherford Backscattering techniques: Geochimica et Cosmochimica Acta, 55, p. 1663-1673, doi: 10.1016/0016-7037(91)90137-T.

Chew, D.M., Petrus, J.A. and Kamber, B.S., 2014. U-Pb LA-ICPMS dating using accessory mineral standards with variable common Pb: Chemical Geology, 363, p. 185-199, doi: 10.1016/j.chemgeo.2013.11.006.

Cochrane, R., Spikings, R.A., Chew, D., Wotzlaw, J.-F., Chiaradia, M., Tyrrell, S., Schaltegger, U. and Van der Lelij, R., 2014. High temperature $\left(>350^{\circ} \mathrm{C}\right)$ thermochronology and mechanisms of $\mathrm{Pb}$ loss in apatite: Geochimica et Cosmochimica Acta, 127, p. 39-56.

Corriveau, L. and Morin, D., 2000. Modelling 3D architecture of western Grenville from surface geology, xenoliths, styles of magma emplacement, and Lithoprobe reflectors: Canadian Journal of Earth Sciences, 37, p. 235-251.

de Sigoyer, J., Vanderhaeghe, O., Duchêne, S. and Billerot, A., 2014. Generation and emplacement of Triassic granitoids within the Songpan Ganze accretionary-orogenic wedge in a context of slab retreat accommodated by tear faulting, Eastern Tibetan plateau, China: Journal of Asian Earth Sciences, 88, p. 192-216, doi: 10.1016/j.jseaes.2014.01.010.

Dodson, M., 1973. Closure temperature in cooling geochronological and petrological systems: Contributions to Mineralogy \& Petrology, 40, p. 259-274.

Dunlap, W.J., 2000. Nature's diffusion experiment: The cooling-rate cooling-age correlation: Geology, 28, p. 139-142, doi: 10.1130/0091-7613(2000)28<139:NDETCC>2.0.CO;2. 
Dunning, G. and Indares, A., 2010. New insights on the 1.7-1.0 Ga crustal evolution of the central Grenville Province from the Manicouagan - Baie Comeau transect: Precambrian Research, 180, p. 204-226, doi: 10.1016/j.precamres.2010.04.005.

Engi, M., Lanari, P. and Kohn, M.J., 2017. Significant Ages - An introduction to petrochronology: Reviews in Mineralogy \& Geochemistry, 83, p. 1-12, doi: 10.2138/rmg.2017.83.1.

Gasquet, D., Bertrand, J.-M., Paquette, J.-L., Lehmann, J., Ratzov, G., Guedes, R.D.A., Tiepolo, M., Boullier, A.-M., Scaillet, S. and Nomade, S., 2010. Miocene to Messinian deformation and hydrothermal activity in a pre-Alpine basement massif of the French western Alps: new U-Th- $\mathrm{Pb}$ and argon ages from the Lauzière massif: Bulletin de la Societe Geologique de France, 181, p. 227-241, doi: 10.2113/gssgfbull.181.3.227.

Harper, C.T., 1967. On the interpretation of potassium-argon ages from Precambrian shields and Phanerozoic orogens: Earth and Planetary Sciences Letters, 3, p. 128-132.

Hoffman, P.F., 1989. Precambrian geology and tectonic history of North America The geology of north America: Geol. Soc. Am., Boulder, CO, United States, p. 447-512.

Indares, A. and Dunning, G., 2004. Crustal architecture above the high-pressure belt of the Grenville Province in the Manicouagan area: new structural, petrologic and $\mathrm{U}-\mathrm{Pb}$ age constraints: Precambrian Research, 130, p. 199-228, doi: 10.1016/j.precamres.2003.11.005.

Jackson, S.E., Pearson, N.J., Griffin, W.L. and Belousova, E.A., 2004. The application of laser ablation-inductively coupled plasma-mass spectrometry to in situ U-Pb zircon geochronology: Chemical Geology, 211, p. 47-69.

Jannin, S., Gervais, F., Moukhsil, A., Augland, L.E. and Crowley, J.L., accepted. Déformations tardi-grenvilliennes dans la Ceinture parautochtone (Province de 
Grenville centrale) : contraintes géochronologiques par couplage de méthodes $\mathrm{U} / \mathrm{Pb}$ de haute résolution spatiale et de haute précision: Canadian Journal of Earth Sciences.

Jamieson, R.A., Beaumont, C., Nguyen, M.H. and Culshaw, N.G. 2007. Synconvergent ductile flow in variable-strength continental crust: Numerical models with application to the western Grenville orogen: Tectonics, 26, TC5005, doi:10.1029/2006TC002036

Jamieson, R.A., Beaumont, C. and Medvedev, S., 2004. Crustal channel flows: 2. Numerical models with implications for metamorphism in the Himalayan-Tibetan orogen. Journal of Geophysical Research, 109, B06407, doi:10.1029/2003JB002811.

Johnson, T.E., Clark, C., Taylor, R.J.M., Santosh, M. and Collins, A.S., 2015. Prograde and retrograde growth of monazite in migmatites: An example from the Nagercoil Block, southern India: Geoscience Frontiers, 6, p. 373-387, doi: 10.1016/j.gsf.2014.12.003.

Jordan, S.L., Indares, A. and Dunning, G., 2006. Partial melting of metapelites in the Gagnon terrane below the high-pressure belt in the Manicouagan area (Grenville Province): pressure-temperature $(\mathrm{P}-\mathrm{T})$ and $\mathrm{U}-\mathrm{Pb}$ age constraints and implications: Canadian Journal of Earth Sciences, 43, p. 1309-1329, doi: 10.1139/E06-038.

Kelsey, D.E., Clark, C. and Hand, M., 2008. Thermobarometric modelling of zircon and monazite growth in melt-bearing systems: examples using model metapelitic and metapsammitic granulites: Journal of Metamorphic Geology, 26, p. 199-212, doi: 10.1111/j.1525-1314.2007.00757.x.

Kohn, M.J., 2008. P-T-t data from central Nepal support critical taper and repudiate largescale channel flow of the Greater Himalayan Sequence: GSA Bulletin, 120, p. 259273, doi: 10.1130/B26252.1.

This article is protected by copyright. All rights reserved. 
Kriegsman, L.M. and Alvarez-Valero, A.M., 2010. Melt-producing versus melt-consuming reactions in pelitic xenoliths and migmatites: Lithos, 116, p. 310-320, doi: 10.1016/j.lithos.2009.09.001.

Lasalle, S., Dunning, G. and Indares, A., 2014. In situ LA-ICP-MS dating of monazite from aluminous gneisses: insights on the tectono-metamorphic history of a granulite-facies domain in the central Grenville Province: Canadian Journal of Earth Sciences, 51, p. 558-572, doi: 10.1139/cjes-2013-0170.

Lasalle, S., Fisher, C.M., Indares, A. and Dunning, G., 2013. Contrasting types of Grenvillian granulite facies aluminous gneisses: Insights on protoliths and metamorphic events from zircon morphologies and ages: Precambrian Research, 228, p. 117-130, doi: 10.1016/j.precamres.2013.01.014.

Lasalle, S. and Indares, A., 2014. Anatectic record and contrasting P-T paths of aluminous gneisses from the central Grenville Province: Journal of Metamorphic Geology, 32, p. 627-646, doi: 10.1111/jmg.12083.

Laurent, O., Couzinié, S., Zeh, A., Vanderhaeghe, O., Moyen, J.-F., Villaros, A., Gardien, V. and Chelle-Michou, C., 2017. Protracted, coeval crust and mantle melting during Variscan late-orogenic evolution: U-Pb dating in the eastern French Massif Central: International Journal of Earth Sciences (Geol Rundsch), 106(2), p. 421-451, doi: 10.1007/s00531-016-1434-9.

Ludwig, K.R., 2001. Isoplot/Ex Version 2.49. A Geochronological Toolkit for Microsoft Excel: Berkeley Geochronology Center, Special Publication, 1a, p. 1-55.

McDowell, F.W., McIntosh, W.C. and Farley, K.A., 2005. A precise 40Ar-39Ar reference age for the Durango apatite (U-Th)/He and fission-track dating standard: Chemical Geology, 214, p. 249-263, doi: 10.1016/j.chemgeo.2004.10.002.

This article is protected by copyright. All rights reserved. 
Moukhsil, A., Solgadi, F., Belkacim, S., Elbasbas, A. and Augland, L.E., 2014. Géologie de la région du lac Okaopéo, Côte-Nord: Ministère de l'Energie et des Ressources Naturelles, Québec, RG 2014-03, 34 p.

Moyen, J.-F., Laurent, O., Chelle-Michou, C., Couzinié, S., Vanderhaeghe, O., Zeh, A., Villaros, A. and Gardien, V., 2017. Collision vs. subduction-related magmatism: Two contrasting ways of granite formation and implications for crustal growth: Lithos, 277, p. 154-177, doi: 10.1016/j.lithos.2016.09.018.

Nelson, K.D., Zhao, W., Brown, L.D., Kuo, J., Che, J., Liu, X., Klemperer, S.L., Makovsky, Y., Meissner, R., Mechie, J., Kind, R., Wenzel, F., Ni, J., Nabelek, J., Leshou, C., Tan, H., Wei, W., Jones, A.G., Booker, J., Unsworth, M., Kidd, W.S.F., Hauck, M., Alsdorf, D., Ross, A., Cogan, M., Wu, C., Sandvol, E. and Edwards, M., 1996. Partially Molten Middle Crust Beneath Southern Tibet: Synthesis of Project INDEPTH Results: Science, 274, p. 1684-1688, doi: 10.2307/2890941.

Paquette, J.L. and Tiepolo, M., 2007. High resolution $(5 \mu \mathrm{m}) \mathrm{U}-\mathrm{Th}-\mathrm{Pb}$ isotope dating of monazite with excimer laser ablation (ELA)-ICPMS: Chemical Geology, 240, p. 222237, doi: 10.1016/j.chemgeo.2007.02.014.

Paquette, J.L., Piro, J.L., Devidal, J.L., Bosse, V., Didier, A., Sanac, S. and Abdelnour, Y., 2014. Sensitivity enhancement in LA-ICP-MS by N2 addition to carrier gas: application to radiometric dating of U-Th-bearing minerals: Agilent ICP-MS J, 58, p. $1-5$

Paton, C., Woodhead, J.D., Hellstrom, J.C., Hergt, J.M., Greig, A. and Maas, R., 2010. Improved laser ablation $\mathrm{U}-\mathrm{Pb}$ zircon geochronology through robust downhole fractionation correction: Geochemistry, Geophysics, Geosystems, 11, p. Q0AA06, doi: 10.1029/2009GC002618.

This article is protected by copyright. All rights reserved. 
Pochon, A., Poujol, M., Gloaguen, E., Branquet, Y., Cagnard, F., Gumiaux, C. and Gapais, D., 2016. U-Pb LA-ICP-MS dating of apatite in mafic rocks: Evidence for a major magmatic event at the Devonian-Carboniferous boundary in the Armorican Massif (France): American Mineralogist, 101, p. 2430-2442, doi: 10.2138/am-2016-5736.

Rivers, T., 2012. Upper-crustal orogenic lid and mid-crustal core complexes: signature of a collapsed orogenic plateau in the hinterland of the Grenville Province: Canadian Journal of Earth Sciences, 49, p. 1-42, doi: 10.1139/E11-014.

Rivers, T., 2008. Assembly and preservation of lower, mid, and upper orogenic crust in the Grenville Province-Implications for the evolution of large hot long-duration orogens: Precambrian Research, 167, p. 237-259, doi: 10.1016/j.precamres.2008.08.005.

Rivers, T., Culshaw, N., Hynes, A., Indares, A., Jamieson, R. and Martignole, J., 2012. The Grenville Orogen - A Post-LITHOPROBE Perspective. In: Tectonic Styles in Canada: The LITHOPROBE Perspective, Geological Association of Canada, Special Paper 49 J.A. Percival, F.A. Cook, and R.M. Clowes, p. 97-236.

Royden, L.H., Burchfiel, B.C. and van der Hilst, R.D., 2008. The Geological Evolution of the Tibetan Plateau: Science, 321, p. 1054-1058, doi: 10.1126/science.1155371.

Royden, L.H., Burchfiel, B.C., King, R.W., Wang, E., Chen, Z., Shen, F. and Liu, Y., 1997. Surface Deformation and Lower Crustal Flow in Eastern Tibet: Science, 276, p. 788790.

Searle, M.P., Elliott, J.R., Phillips, R.J. and Chung, S.L., 2011. Crustal-lithospheric structure and continental extrusion of Tibet: Journal of the Geological Society, London, 168, p. 633-672, doi: 10.1144/0016-76492010-139.

This article is protected by copyright. All rights reserved. 
Schoene, B. and Bowring, S.A., 2007. Determining accurate temperature-time paths from U$\mathrm{Pb}$ thermochronology: An example from the Kaapvaal craton, southern Africa: Geochimica et Cosmochimica Acta, 71, p. 165-185, doi: 10.1016/j.gca.2006.08.029.

Schoene, B. and Bowring, S.A., 2006. U-Pb systematics of the McClure Mountain syenite: thermochronological constraints on the age of the 40Ar/39Ar standard MMhb: Contributions to Mineralogy and Petrology, 151, p. 615, doi: 10.1007/s00410-0060077-4.

Slagstad, T., Hamilton, M.A., Jamieson, R.A. and Culshaw, N.G., 2004. Timing and duration of melting in the mid orogenic crust: Constraints from U-Pb (SHRIMP) data, Muskoka and Shawanaga domains, Grenville Province, Ontario: Canadian Journal of Earth Sciences, 41, p. 1339-1365, doi: 10.1139/e04-068.

Stacey, J.S. and Kramers, J.D., 1975. Approximation of terrestrial lead isotope evolution by a two-stage model: Earth and Planetary Science Letters, 26, p. 207-221, doi: $10.1016 / 0012-821 X(75) 90088-6$.

Tera, F. and Wasserburg, G.J., 1972. U-Th-Pb systematics in lunar highland samples from the Luna 20 and Apollo 16 missions: Earth and Planetary Science Letters, 17, p. 36-51, doi: 10.1016/0012-821X(72)90257-9.

Thomson, S.N., Gehrels, G.E., Ruiz, J. and Buchwaldt, R., 2012. Routine low-damage apatite $\mathrm{U}-\mathrm{Pb}$ dating using laser ablation-multicollector-ICPMS: Geochemistry, Geophysics, Geosystems, 13, p. Q0AA21, doi: 10.1029/2011GC003928.

Turlin, F., André-Mayer, A.-S., Moukhsil, A., Vanderhaeghe, O., Gervais, F., Solgadi, F., Groulier, P.-A. and Poujol, M., 2017. Unusual LREE-rich, peraluminous, monaziteor allanite-bearing pegmatitic granite in the central Grenville Province, Québec: Ore Geology Reviews, 89, p. 627-667, doi: 10.1016/j.oregeorev.2017.04.019.

This article is protected by copyright. All rights reserved. 
Van Achterbergh, E., Ryan, C.G., Jackson, S.E. and Griffin, W.L., 2001. Data reduction software for LA-ICP-MS: appendix: Laser-Ablation-ICPMS in the earth sciencesprinciples and applications. Miner Assoc Can (short course series), 29, p. 239-243.

van Gool, J.A.M., Rivers, T. and Calon, T., 2008. Grenville Front zone, Gagnon terrane, southwestern Labrador: configuration of a midcrustal foreland fold-thrust belt: Tectonics, 27, TC1004, doi: 10.1029/2006TC002095.

Vanderhaeghe, O., 2001. Melt segragation, pervasive melt migration and magma mobility in the continental crust: the structural record from pores to orogens: Physics and Chemistry of the Earth, Part A: Solid Earth and Geodesy, 26, p. 213-223, doi: 10.1016/S1464-1895(01)00048-5.

Vanderhaeghe, O. and Teyssier, C., 2001b. Partial melting and flow of orogens: Tectonophysics, 342, p. 451-472.

Vanderhaeghe, O., 2009. Migmatites, granites and orogeny: Flow modes of partially-molten rocks and magmas associated with melt/solid segregation in orogenic belts: Tectonophysics, 477, p. 119-134, doi: 10.1016/j.tecto.2009.06.021.

Vanderhaeghe, O., 2012. The thermal-mechanical evolution of crustal orogenic belts at convergent plate boundaries: A reappraisal of the orogenic cycle: Journal of Geodynamics, 56-57, p. 124-145, doi: 10.1016/j.jog.2011.10.004.

Yakymchuk, C., 2017. Behaviour of apatite during partial melting of metapelites and consequences for prograde suprasolidus monazite growth: Lithos, 274-275, p. 412426, doi: 10.1016/j.lithos.2017.01.009.

Yakymchuk, C. and Brown, M., 2014. Behaviour of zircon and monazite during crustal melting: Journal of the Geological Society, 171, p. 465-479, doi: 10.1144/jgs2013115.

This article is protected by copyright. All rights reserved. 
Yakymchuk, C., Clark, C. and White, R.W., 2017. Phase Relations, Reaction Sequences and Petrochronology: Reviews in Mineralogy \& Geochemistry, 83, p. 13-53, doi: 10.2138/rmg.2017.83.2.

\section{Supplementary material:}

\section{S1. Sampling}

S2. Analytical methods: Electron probe microanalyser (EPMA)

S3. Analytical methods: U-Th-Pb dating using Laser Ablation - Inductively Coupled Plasma - Mass Spectrometry (LA-ICP-MS)

\section{FIGURE CAPTIONS}

Figure 1. (a): position of the Grenville orogen in Laurentia. Palaeozoic and younger cover omitted (modified from Hoffman, 1989; Rivers, 2008; Rivers et al., 2012). The northern dashed line represents the boundary between Internal and External Palaeoproterozoic Laurentia and the southern dashed line represents the Grenville Front (GF); (b): simplified tectonic map of the Grenville Province (modified after Rivers, 2008; Rivers et al., 2012); (c): geological map of the central Grenville Province (Quebec) showing the position of the investigated paragneisses (star) and of data from literature discussed in this study (circles and squares) (modified after Moukhsil et al., 2014; Turlin et al., 2017). U-Th-Pb ages on monazite and apatite from this study are reported in regular and bold text, respectively. Abbreviations: 1 = exposed Grenville Province, light grey represents the inferred extension of subsurface allochthonous Grenville Province; 2 = Granite-Rhyolite Igneous Province, ca. 1.50-1.34 Ga and reworked equivalents in the Grenville Province; $3=$ Mid-Continental Rift system; 4 = Palaeoproterozoic orogens, ca. 1.9-1.8 Ga, ca. 1.65 Ga and reworked equivalents in the Grenville Province; $5=$ Archaean cratons; ABT = Allochthon Boundary Thrust; Gagnon T. $=$ Gagnon Terrane; GF = Grenville Front; MIZ = Manicouagan Imbricate Zone . 
Figure 2. Sampled migmatitic paragneisses and phase relationships of the leucosome. (a): lobate contact between the migmatitic paragneisses and the intrusive $1005 \pm 4.4$ Ma pegmatitic granite dyke (Turlin et al., 2017) with no evidence for contact metamorphism nor thermal exchange between the dyke and the host paragneisses that collectively support a close to wetsolidus temperature of the host at ca. $1005 \mathrm{Ma}$; (b): hand sample of the investigated paragneisses. Note the magmatic texture of the leucosomes with no preferred mineral orientation; (c): microstructural setting of apatite in the leucosome. Note the magmatic texture of the apatite and the lack of corrosion and dissolution/precipitation textures; (d): corroded biotite, nearly skeletal, separated from peritectic garnet by K-feldspar. This texture points to the uncomplete biotite dehydration reaction at the $P-T$ peak of metamorphism (maximum temperature); (e): prograde monazite shielded in peritectic garnet; (f): magmatic subhedral apatite in the Qtz+Pl+K-Fsp+Bt leucosome matrix. Abbreviations: Alloch. = allochthonous; $\mathrm{Ap}=$ apatite $; \mathrm{Bt}=$ biotite Grt = garnet; K-Fsp = K-feldspar; Mnz = monazite; $\mathrm{PGD}=$ pegmatitic granite dyke $; \mathrm{Pl}=$ plagioclase $; \mathrm{Py}=$ pyrite $; \mathrm{Qtz}=$ quartz $; \mathrm{Xnt}=$ xenotime .

Figure 3. $\mathrm{U}-\mathrm{Th}-\mathrm{Pb}$ dating of the leucosome of migmatitic paragneisses from the Allochthonous Belt of the central Grenville Province. (a): Concordia plots for monazite analyses $(n=21)$; (b): Tera-Wasserburg concordia diagram for apatite analyses $(n=23)$.

Figure 4. Time vs temperature diagram of aluminous gneisses from the mid-pressure crustal segment of the central Grenville Province considered in this study. It was constructed using the geochronological data and thermometric constraints from this study and those reported by Dunning and Indares (2010), Indares and Dunning (2004), Lasalle and Indares (2014) and Lasalle et al. (2014). Temperatures of partial melting reactions are from Lasalle and Indares (2014). The suprasolidus prograde $T-t$ path is recorded by shielded monazite in peritectic garnet and K-feldspar up to a temperature of ca. $850^{\circ} \mathrm{C}$ characterized by the biotite breakdown by dehydration melting characterized by the corroded texture of biotite and its 
separation from peritectic garnet by K-feldspar. The suprasolidus, or close to suprasolidus, retrograde $T-t$ path is recorded by monazite from the matrix and down to ca. $1005 \mathrm{Ma}$ as evidenced by the intrusion of a pegmatitic granite dyke into paragneisses which lobate contact with no evidence of contact metamorphism nor thermal exchange with the host evidence for the close to wet-solidus temperature of the host. The retrograde $T-t$ path is recorded by titanite from the same segment and dated between ca. 1000 and $975 \mathrm{Ma}$, and by apatite from the matrix of the investigated leucosome dated at ca. $960 \pm 10 \mathrm{Ma}$ with isotopic closure temperatures of ca. $440-550^{\circ} \mathrm{C}$. Abbreviations: $\mathrm{Ap}=$ apatite; $\mathrm{Bt}=$ biotite; $\mathrm{Mnz}=$ monazite; $\mathrm{Ms}=$ muscovite; $\mathrm{PGD}=$ pegmatitic granite dyke; $\mathrm{Tc}=$ isotopic closure temperature.

Figure 5. Schematic cross sections illustrating the thermal evolution of the high and mid pressure crustal segments of the Allochthonous Belt of the central Grenville Province (after Rivers, 2008). (a): Ottawan prograde $P-T$ path (ca. 1090-1080 Ma) and peak of metamorphism (ca. 1070-1050 Ma) marked by the development of a channel flow in the high and mid pressure crustal segments of the Allochthonous Belt; (b): suprasolidus conditions are preserved within high and mid pressure crustal segments of the Allochthonous Belt from ca. $1050 \mathrm{Ma}$ down to ca. $1005 \mathrm{Ma}$ corresponding to the timing of intrusion of the 13-TC-5008 pegmatitic granite dyke (Turlin et al., 2017); (c): cooling down to subsolidus conditions of the mid pressure crustal segments of the Allochthonous Belt at ca. 960 Ma. Abbreviations: $\mathrm{ABT} / \mathrm{ABD}=$ Allochthonous Boundary Thrust/Detachment; $\mathrm{aH} P=$ allochthonous high pressure Ottawan crust; aM-LP = allochthonous mid-low pressure Ottawan crust; Paraut. crust $=$ Parautochthonous crust PGD $=$ pegmatitic granite dyke.

This article is protected by copyright. All rights reserved. 
Table 1. U-Th- $\mathrm{Pb}$ dating of monazite from a leucosome of migmatitic allochthonous paragneisses from the central Grenville Province.

\begin{tabular}{|c|c|c|c|c|c|c|c|c|c|c|c|}
\hline \multirow{2}{*}{ Analysis no. } & \multicolumn{3}{|c|}{ Concentrations } & \multicolumn{4}{|c|}{ Isotopic ratios } & \multicolumn{4}{|l|}{ Ages/Ma } \\
\hline & $\mathrm{Pb}$ (ppm) & U (ppm) & Th (ppm) & ${ }^{206} \mathrm{~Pb} /{ }^{238} \mathrm{U}$ & 2 & ${ }^{208} \mathrm{~Pb} /{ }^{232} \mathrm{Th}$ & 2 & ${ }^{206} \mathrm{~Pb} /{ }^{238} \mathrm{U}$ & 2 & ${ }^{208} \mathrm{~Pb} /{ }^{232} \mathrm{Th}$ & 2 \\
\hline Mnz-03 & 2568 & 5657 & 35563 & 0.1754 & 0.0046 & 0.0538 & 0.0013 & 1042 & 25 & 1058 & 25 \\
\hline Mnz-04 & 2874 & 10542 & 28447 & 0.1744 & 0.0046 & 0.0534 & 0.0013 & 1036 & 25 & 1051 & 25 \\
\hline Mnz-06 & 2365 & 7613 & 26481 & 0.1746 & 0.0046 & 0.0535 & 0.0013 & 1038 & 25 & 1054 & 25 \\
\hline Mnz-07 & 2748 & 6731 & 37166 & 0.1753 & 0.0047 & 0.0533 & 0.0013 & 1041 & 26 & 1049 & 25 \\
\hline Mnz-08 & 3577 & 17411 & 23848 & 0.1752 & 0.0047 & 0.0536 & 0.0013 & 1041 & 26 & 1055 & 25 \\
\hline Mnz-09 & 2586 & 5887 & 35691 & 0.1767 & 0.0048 & 0.0542 & 0.0013 & 1049 & 26 & 1066 & 25 \\
\hline Mnz-10 & 2583 & 5744 & 36107 & 0.1769 & 0.0048 & 0.0541 & 0.0013 & 1050 & 26 & 1066 & 25 \\
\hline Mnz-11 & 2878 & 6435 & 40465 & 0.1757 & 0.0048 & 0.0540 & 0.0013 & 1044 & 26 & 1062 & 25 \\
\hline Mnz-12 & 2495 & 6866 & 30822 & 0.1781 & 0.0049 & 0.0548 & 0.0013 & 1057 & 27 & 1077 & 26 \\
\hline Mnz-13 & 2584 & 6776 & 34297 & 0.1737 & 0.0048 & 0.0537 & 0.0013 & 1032 & 27 & 1057 & 25 \\
\hline Mnz-14 & 3187 & 6099 & 48278 & 0.1758 & 0.0049 & 0.0540 & 0.0013 & 1044 & 27 & 1062 & 26 \\
\hline Mnz-15 & 2378 & 6356 & 31272 & 0.1753 & 0.0049 & 0.0536 & 0.0013 & 1041 & 27 & 1056 & 25 \\
\hline Mnz-16 & 2384 & 6332 & 31314 & 0.1764 & 0.0050 & 0.0538 & 0.0013 & 1047 & 27 & 1059 & 26 \\
\hline Mnz-17 & 3078 & 9311 & 37637 & 0.1750 & 0.0050 & 0.0536 & 0.0013 & 1040 & 27 & 1055 & 26 \\
\hline Mnz-18 & 2465 & 6522 & 32261 & 0.1771 & 0.0051 & 0.0542 & 0.0013 & 1051 & 28 & 1066 & 26 \\
\hline Mnz-19 & 2650 & 7494 & 34203 & 0.1760 & 0.0052 & 0.0534 & 0.0013 & 1045 & 28 & 1051 & 26 \\
\hline Mnz-20 & 3080 & 10383 & 34931 & 0.1742 & 0.0052 & 0.0540 & 0.0014 & 1035 & 28 & 1063 & 26 \\
\hline Mnz-21 & 3043 & 7898 & 40976 & 0.1760 & 0.0053 & 0.0540 & 0.0014 & 1045 & 29 & 1063 & 26 \\
\hline Mnz-22 & 4040 & 17441 & 34861 & 0.1765 & 0.0053 & 0.0538 & 0.0014 & 1048 & 29 & 1058 & 26 \\
\hline Mnz-23 & 2946 & 8983 & 35659 & 0.1793 & 0.0055 & 0.0538 & 0.0014 & 1063 & 30 & 1059 & 26 \\
\hline Mnz-24 & 2416 & 5590 & 34395 & 0.1796 & 0.0055 & 0.0538 & 0.0014 & 1065 & 30 & 1060 & 26 \\
\hline
\end{tabular}

Table 2. $\mathrm{U}-\mathrm{Pb}$ dating of apatite from a leucosome of migmatitic allochthonous paragneisses

from the central Grenville Province.

\begin{tabular}{|c|c|c|c|c|c|c|}
\hline \multirow[t]{2}{*}{ Analysis no. } & \multirow{2}{*}{$\begin{array}{c}\text { Concentrations } \\
\text { Pb (ppm) }\end{array}$} & \multirow[b]{2}{*}{$\mathbf{U}(\mathbf{p p m})$} & \multicolumn{2}{|c|}{ Isotopic ratios } & \multirow[b]{2}{*}{${ }^{207} \mathrm{~Pb} /{ }^{206} \mathrm{~Pb}$} & \multirow[b]{2}{*}{2} \\
\hline & & & ${ }^{238} \mathrm{U} /{ }^{206} \mathrm{~Pb}$ & 2 & & \\
\hline Ap-1 & 3.5 & 18 & 4.77 & 0.16 & 0.2487 & 0.0031 \\
\hline Ap-2 & 3.3 & 20 & 5.02 & 0.17 & 0.2281 & 0.0028 \\
\hline Ap-3 & 2.5 & 35 & 5.61 & 0.19 & 0.1476 & 0.0019 \\
\hline Ap-4 & 3.0 & 57 & 5.82 & 0.19 & 0.1290 & 0.0014 \\
\hline Ap-5 & 3.0 & 58 & 5.86 & 0.20 & 0.1295 & 0.0018 \\
\hline Ap-6 & 3.8 & 54 & 5.68 & 0.19 & 0.1470 & 0.0018 \\
\hline Ap-7 & 27 & 179 & 5.14 & 0.17 & 0.2106 & 0.0028 \\
\hline Ap-8 & 17 & 90 & 4.98 & 0.17 & 0.2458 & 0.0033 \\
\hline Ap-9 & 25 & 318 & 5.64 & 0.19 & 0.1469 & 0.0017 \\
\hline Ap-10 & 50 & 149 & 4.37 & 0.15 & 0.3082 & 0.0050 \\
\hline Ap-11 & 71 & 419 & 4.68 & 0.16 & 0.2776 & 0.0041 \\
\hline Ap-12 & 14 & 102 & 5.03 & 0.17 & 0.2109 & 0.0033 \\
\hline Ap-13 & 3.2 & 5.8 & 3.41 & 0.13 & 0.4336 & 0.0085 \\
\hline Ap-14 & 3.5 & 5.4 & 3.21 & 0.11 & 0.4878 & 0.0098 \\
\hline Ap-15 & 4.8 & 33 & 5.04 & 0.17 & 0.2119 & 0.0028 \\
\hline Ap-16 & 5.7 & 38 & 5.08 & 0.18 & 0.2227 & 0.0036 \\
\hline Ap-17 & 6.4 & 44 & 5.04 & 0.18 & 0.2213 & 0.0039 \\
\hline Ap-18 & 9.1 & 40 & 4.56 & 0.16 & 0.2833 & 0.0049 \\
\hline Ap-19 & 7.3 & 94 & 5.83 & 0.20 & 0.1534 & 0.0028 \\
\hline Ap-20 & 7.8 & 93 & 5.63 & 0.19 & 0.1568 & 0.0019 \\
\hline Ap-21 & 7.4 & 88 & 5.59 & 0.19 & 0.1554 & 0.0016 \\
\hline Ap-22 & 7.2 & 100 & 5.83 & 0.19 & 0.1465 & 0.0017 \\
\hline Ap-23 & 5.9 & 30 & 4.89 & 0.17 & 0.2461 & 0.0030 \\
\hline
\end{tabular}

This article is protected by copyright. All rights reserved. 
Table 3. Closure temperature of investigated apatite calculated on the basis of their stubby and euhedral to subhedral, crystal diameters of 300 and $600 \mu \mathrm{m}$, and a range of typical lateto post-Grenvillian and ca. $1 \mathrm{Ga}$ orogens cooling rates of $1{ }^{\circ} \mathrm{C} / \mathrm{Ma}, 3^{\circ} \mathrm{C} / \mathrm{Ma}, 5^{\circ} \mathrm{C} / \mathrm{Ma}$ and $7^{\circ} \mathrm{C} / \mathrm{Ma}$ (e.g. Rivers et al., 2012; Dunlap, 2000).

\begin{tabular}{cccc}
\hline $\begin{array}{c}\text { Crystal diameter } \\
(\boldsymbol{\mu m})\end{array}$ & $\begin{array}{c}\text { Cooling rate } \\
\left({ }^{\circ} \mathbf{C} / \mathbf{M a}\right)\end{array}$ & $\begin{array}{c}\text { Closure temperatures } \\
\left({ }^{\circ} \mathbf{C}\right)\end{array}$ & $\begin{array}{c} \pm \\
\left({ }^{\circ} \mathbf{C}\right)\end{array}$ \\
\hline 300 & 1 & 459 & 22 \\
600 & 1 & 485 & 23 \\
300 & 3 & 479 & 23 \\
600 & 3 & 507 & 24 \\
300 & 5 & 489 & 23 \\
600 & 5 & 518 & 24 \\
300 & 7 & 497 & 24 \\
600 & 7 & 526 & 24 \\
\hline
\end{tabular}

${ }^{1}$ : Calculated using the Dodson (1973)'s equation with data from Cherniak et al. (1991)

Table 4. Grenvillian cooling rates calculated using data from the literature coupled with the data presented in this study on a single leucosome from migmatitic paragneisses of the central Grenville Province. Note the similar cooling rates obtained for both Ottawan and postOttawan orogenic phases suggesting a continuum of cooling from the former through to the latter.

\begin{tabular}{cccc}
\hline $\begin{array}{c}\text { Grenvillian orogenic } \\
\text { phase }\end{array}$ & $\begin{array}{c}\text { Age } \\
(\mathbf{M a})\end{array}$ & $\begin{array}{c}\text { Temperature } \\
\left({ }^{\circ} \mathbf{C}\right)\end{array}$ & $\begin{array}{c}\text { Cooling rate } \\
\left({ }^{\circ} \mathbf{C} / \mathbf{M a}\right)\end{array}$ \\
\hline \hline \multirow{2}{*}{ Ottawan } & $1070-1050^{1}$ & $850^{1}$ & $2.3-4.4$ \\
\hline \multirow{2}{*}{ Post-Ottawan } & $1005^{2}$ & $650-700^{2}$ & $3.9-7.5^{6}$ \\
& $960 \pm 10^{3}$ & $437^{4}$ & $1.8^{6}-4.3$ \\
\hline
\end{tabular}

${ }^{1}$ : Temperature and timing of the peak metamorphism from Lasalle and Indares (2014).

${ }^{2}$ : Close to wet-solidus temperature of the migmatitic paragneisses at the time of intrusion of the pegmatitic granite dyke (Turlin et al., 2017).

${ }^{3}$ : Subsolidus timing of apatite isotopic closure (this study).

${ }^{4}$ : Minimum closure temperature of investigated apatite grains (this study).

5: Maximum closure temperature of investigated apatite grains (this study)

${ }^{6}$ : Extreme values. Cooling rates are predominantly in the range 2.7 to $6.1^{\circ} \mathrm{C} / \mathrm{Ma}$.

This article is protected by copyright. All rights reserved. 
Turlin et al. - Figure 1 (color; page width)

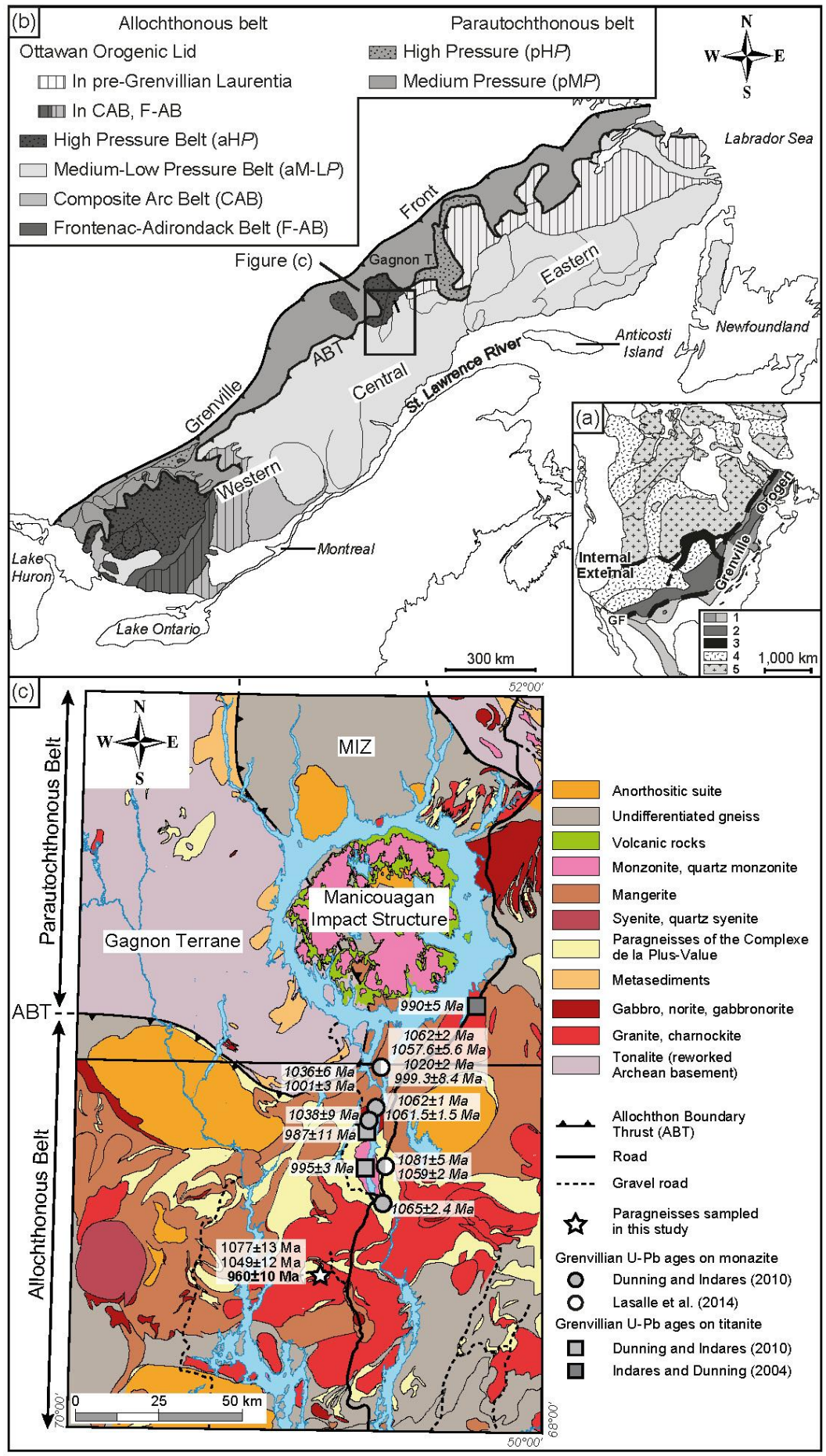

This article is protected by copyright. All rights reserved. 
Turlin et al. - Figure 2 (color; two-thirds of the page)

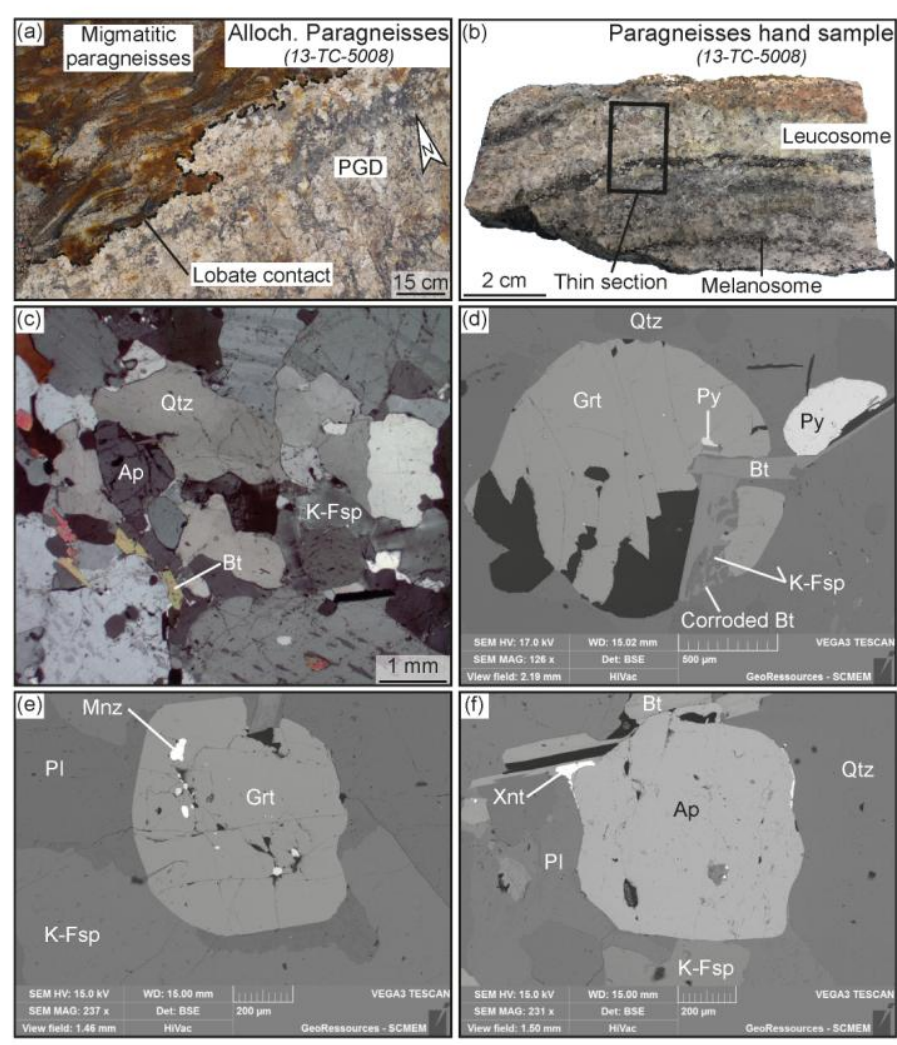

This article is protected by copyright. All rights reserved. 
Turlin et al. - Figure 3

(black and white; one column)
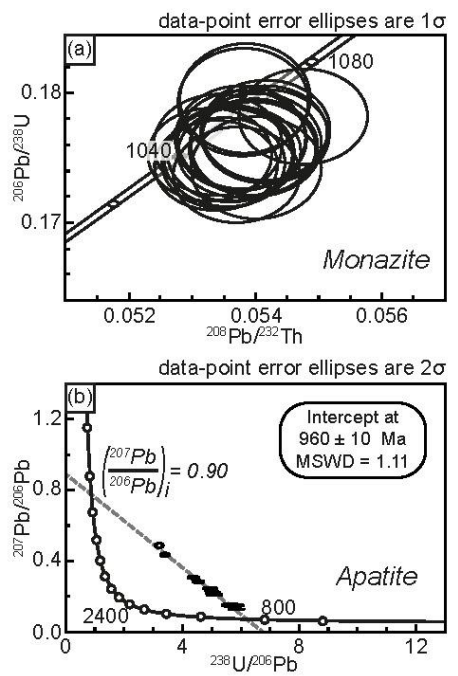

This article is protected by copyright. All rights reserved. 
Turlin et al. - Figure 4 (black and white; two-thirds of the page)

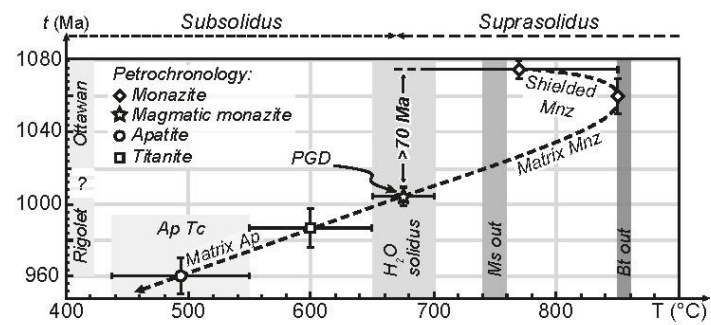

This article is protected by copyright. All rights reserved. 
Turlin et al. - Figure 5 (color; page width)

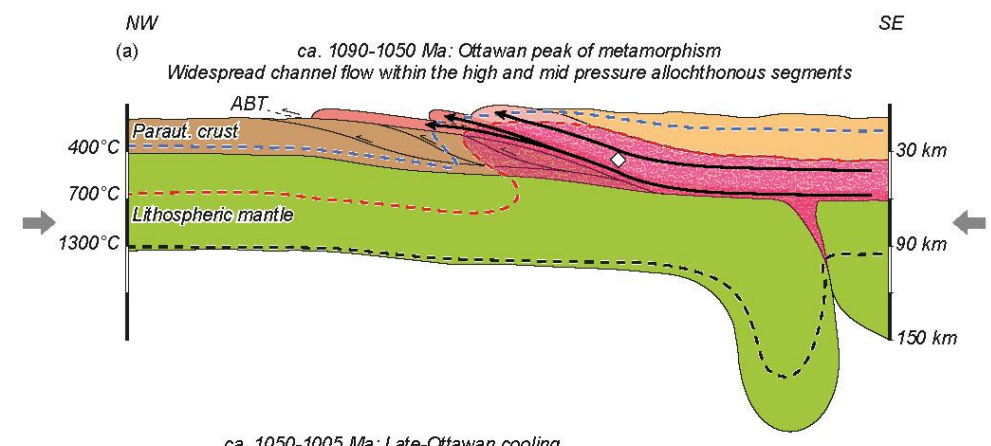

ca. 1050-1005 Ma: Late-Ottawan cooling
(b) Preservation of suprasolidus conditions in high and mid pressure a

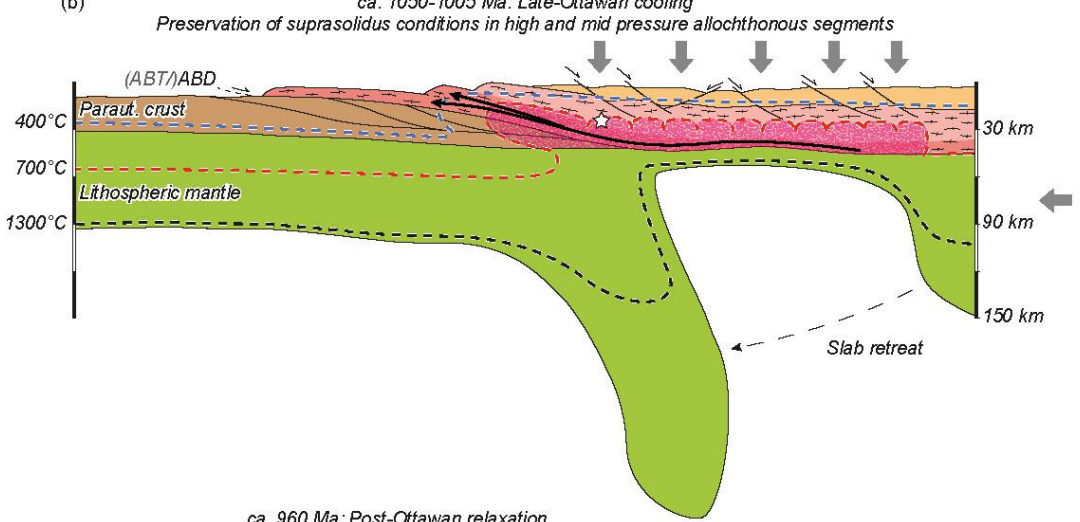

(c)

Cooling down to subsolids. $960 \mathrm{Ma}$ : Post-Ottawan relaxation

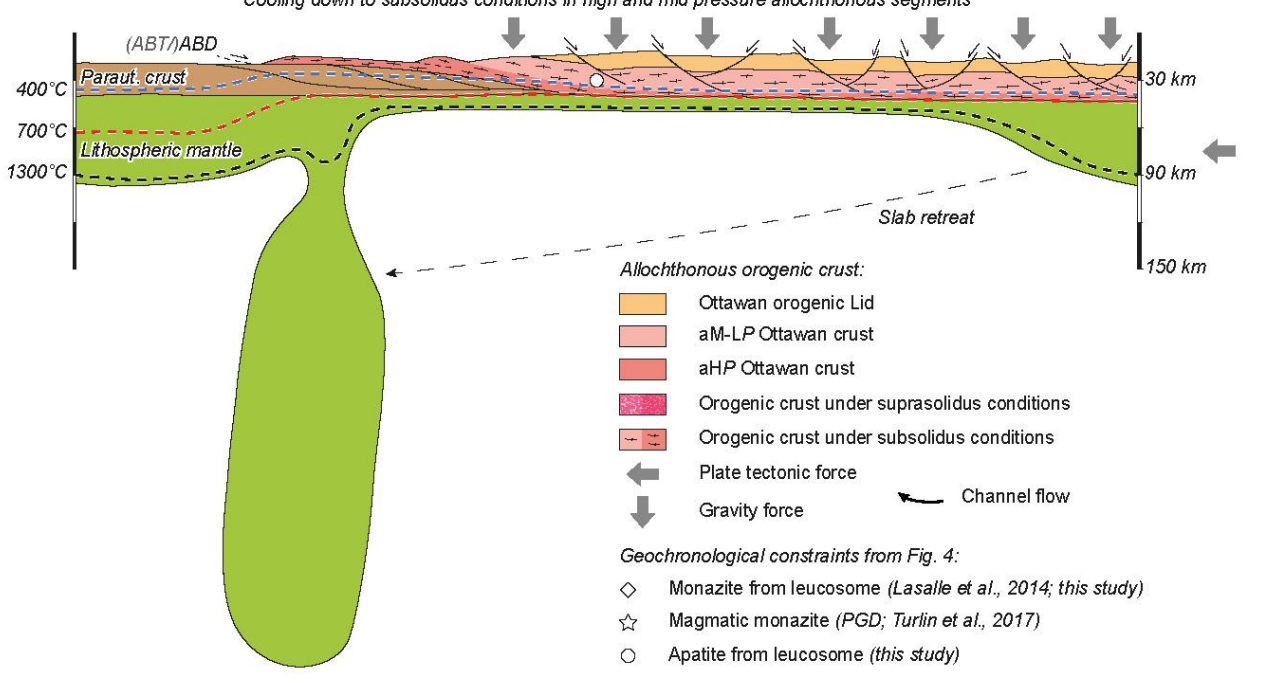

This article is protected by copyright. All rights reserved. 